\title{
Forest fire danger forecasting in Poland
}

\author{
J. Piwnicki, B. Ubysz \& R. Szczygieł \\ Independent Forest Fire Protection Laboratory, \\ Forest Research Institute, Poland
}

\begin{abstract}
This paper describes the method of forest fire danger assessment in Poland depending on dynamic weather changes. The degree of forest fire danger influences the type of organizational actions, which the forest administration and rescue units are obliged to take on a given day. Apart from that, an analysis of basic meteorological factors influencing the degree of forest fire danger in 2007 and occurrence of forest fires in the fire season was presented.
\end{abstract}

Keywords: forest fire danger, fire season, litter humidity.

\section{Introduction}

The purpose of forest fire danger forecasting is to establish the likelihood of fire on a given day and on the next day, depending on dynamic weather changes. The degree of forest fire danger influences the type of organizational actions, which the forest division or national park administration are obliged to take on a given day (Table 1). In Poland, degree of forest fire danger risk is established with the use of the IBL (Instytut Badań Leśnictwa, Forest Research Institute) method for administrative units of the Polish State Forests, in 34 forecast zones (since 2008: in 42 zones). Division of forest areas into zones is made by the General Directorate of the State Forests on request of the Independent Forest Fire Protection Laboratory of the Forest Research Institute. The following features are used as the criteria for the division: degrees of forest fire danger risk, presence of large, dense forest complexes, location in certain natural and forest areas, climatic homogeneity, habitat and forest stand conditions, frequency and size of forest fires, radio and telephone communications within the zone, administrative division of the State Forests as well as the presence of large urban agglomerations, industrial areas and high tourist traffic areas. The basic organizational unit is a forest division (average area: ca. 20,000 ha). 
Table 1: $\quad$ Protective measures of regional directorates of the State Forests and National Parks depending on actual degree of forest danger.

\begin{tabular}{|c|c|c|c|c|c|}
\hline No & Type of activity & $\mathbf{0}$ & 1 & 2 & 3 \\
\hline \multirow[t]{6}{*}{1.} & a) Alarm-command points activated & & + & + & + \\
\hline & $\begin{array}{l}\text { b) Maintenance of duties at the alarm-command } \\
\text { points also after working hours }\end{array}$ & & + & + & + \\
\hline & $\begin{array}{l}\text { c) Strengthening of duties at alarm-command points: } \\
\text { plenipotentiaries of the chief forest officer present } \\
\text { in the office or on stand by at home - with a } \\
\text { transportation means }\end{array}$ & & & + & + \\
\hline & d) Duties at observational points & & + & + & + \\
\hline & $\begin{array}{l}\text { e) Dispatch of ground lookout patrols in particularly } \\
\text { heavily endangered regions }\end{array}$ & & & & + \\
\hline & f) Dispatch of aerial patrols & & & + & + \\
\hline \multirow[t]{2}{*}{2.} & $\begin{array}{l}\text { a) Personnel of special fire suppression equipment } \\
\text { on stand by }\end{array}$ & & + & + & + \\
\hline & $\begin{array}{|lll|}\text { b) Personnel of other technical suppression } \\
\text { equipment on stand by }\end{array}$ & & & + & + \\
\hline 3. & $\begin{array}{l}\text { Public access to forest closed. Stand by for the } \\
\text { whole Forest District or National Park personnel }\end{array}$ & & & & + \\
\hline 4. & $\begin{array}{l}\text { Take-off time needed for airplanes in the Forest } \\
\text { Aerial Bases }\end{array}$ & & $\begin{array}{c}15-20 \\
\min \end{array}$ & $\begin{array}{c}\text { to } 10 \\
\min \end{array}$ & $\begin{array}{l}\text { to } 5 \\
\min \end{array}$ \\
\hline 5. & $\begin{array}{l}\text { Coordination of activity by Regional Directorate of } \\
\text { State Forests }\end{array}$ & + & + & + & + \\
\hline
\end{tabular}

\section{Fire danger risk forecasting method}

The degree of forest fire danger risk for a forecast zone is established on the basis of the following parameters:

a) litter humidity in a pine forest stand of III age class (from 41 to 60 year), growing on a fresh forest habitat,

b) relative humidity of the air measured at the height of $0.5 \mathrm{~m}$ above ground level,

c) precipitation coefficient, correcting the degree of forest fire danger risk.

Every day, at 9:00 and 13:00, current values of meteorological parameters are measured at several auxiliary meteorological points for a given zone and transferred to the forecast point of that zone. At that point, apart from meteorological factors, the litter humidity value is established and the current degree of fire danger for 9:00 and 13:00 is established according to Table 2 .

If the measurement of litter humidity at the auxiliary measurement point is not carried out, the precipitation coefficient calculated for that point corrects the degree of forest fire danger risk specified for the auxiliary measurement point (Table 3). 
Table 2: $\quad$ Degrees of forest fire danger risk (DFFDR) and the corresponding values of litter humidity and relative humidity of the air.

\begin{tabular}{|c|c|c|c|c|}
\hline \multirow{3}{*}{$\begin{array}{l}\text { DFFDR at the forecast } \\
\text { point and auxiliary } \\
\text { measurement points }\end{array}$} & \multicolumn{4}{|c|}{ Humidity value (in \%) measured at } \\
\hline & \multicolumn{2}{|c|}{$9^{00}$} & \multicolumn{2}{|c|}{$13^{00}$} \\
\hline & litter & Air & litter & Air \\
\hline $\begin{array}{l}\text { No danger risk } \\
0 . \text { degree }\end{array}$ & $\begin{array}{c}0-60 \\
61-75\end{array}$ & $\begin{array}{c}96-100 \\
0-100\end{array}$ & $\begin{array}{c}0-40 \\
41-75\end{array}$ & $\begin{array}{c}86-100 \\
0-100\end{array}$ \\
\hline $\begin{array}{c}\text { Low danger risk } \\
\text { 1. degree }\end{array}$ & $\begin{array}{c}0-40 \\
41-60\end{array}$ & $\begin{array}{c}86-95 \\
0-95\end{array}$ & $\begin{array}{c}0-30 \\
31-40\end{array}$ & $\begin{array}{c}66-85 \\
0-85\end{array}$ \\
\hline $\begin{array}{l}\text { Moderate danger risk } \\
\text { 2. degree }\end{array}$ & $\begin{array}{c}0-20 \\
21-40\end{array}$ & $\begin{array}{l}76-85 \\
0-85\end{array}$ & $\begin{array}{c}0-15 \\
16-30\end{array}$ & $\begin{array}{l}51-65 \\
0-65\end{array}$ \\
\hline $\begin{array}{l}\text { High danger risk } \\
\text { 3. degree }\end{array}$ & $0-20$ & $0-75$ & $0-15$ & $0-50$ \\
\hline
\end{tabular}

Table 3: $\quad$ Principles of adjustment of the degree of forest fire danger risk for the auxiliary measurement point.

\begin{tabular}{|c|c|c|}
\hline \multirow{2}{*}{ Difference in precipitation $[\mathrm{mm}]$} & \multicolumn{2}{|c|}{$\begin{array}{l}\text { DFFDR at the auxiliary measurement } \\
\text { point (mp) with precipitation at the } \\
\text { forecast point that is }\end{array}$} \\
\hline & $\begin{array}{l}\text { higher than the } \\
\text { precipitation at the } \\
\text { auxiliary mp }\end{array}$ & $\begin{array}{l}\text { lower than the } \\
\text { precipitation at the } \\
\text { auxiliary mp }\end{array}$ \\
\hline $\begin{array}{l}\text { Precipitation value up to } 5 \mathrm{~mm} \\
\text { Difference up to } 5 \mathrm{~mm}\end{array}$ & \multicolumn{2}{|c|}{ calculated degree remains unchanged } \\
\hline $\begin{array}{l}\text { Difference from } \\
5.1 \text { to } 10.0 \mathrm{~mm}\end{array}$ & $\begin{array}{l}\text { calculated degree is } \\
\text { increased by } 1\end{array}$ & $\begin{array}{c}\text { calculated degree is } \\
\text { decreased by } 1\end{array}$ \\
\hline $\begin{array}{l}\text { Difference from } \\
10.1 \text { to } 20.0 \mathrm{~mm}\end{array}$ & $\begin{array}{c}\text { calculated degree is } \\
\text { increased by } 2\end{array}$ & $\begin{array}{c}\text { calculated degree is } \\
\text { decreased by } 2\end{array}$ \\
\hline $\begin{array}{c}\text { Local precipitation } \\
\text { difference exceeding } 20.0 \mathrm{~mm}\end{array}$ & $\begin{array}{l}\text { calculated degree is } \\
\text { increased by } 3\end{array}$ & $\begin{array}{l}\text { degree assumes } \\
\text { takes on the zero }\end{array}$ \\
\hline $\begin{array}{l}\text { Precipitation in the whole zone } \\
\text { or constant precipitation }\end{array}$ & \multicolumn{2}{|c|}{ calculated degree remains unchanged } \\
\hline
\end{tabular}

Generally speaking, forest fire danger risk forecasting is conducted by the State Forests in the period of the so-called fire danger season in Poland, i.e. from $1^{\text {st }}$ April to $30^{\text {th }}$ September. Fire danger risk maps, prepared on a daily basis in the fire season are published on an ongoing basis in the Internet, at http://zagrozeniepozarowe.ibles.pl.

\section{The basic meteorological factors and fire danger risk}

The seasonality of forest fires occurrence is closely connected with the weather. The volume of precipitation in the 2007 fire season was differentiated both as 
regards their occurrence in time and their distribution within the territory of Poland. The total amount of precipitation was from $0.7 \mathrm{~mm}$ to $249 \mathrm{~mm}$ in individual months and took on the multi-year norm values from 1 to $405 \%$. The highest amount of precipitation was recorded in August (on average, 231\% of multi-year norm, which corresponds to $155 \mathrm{~mm}$ of precipitation). Precipitation that was significantly lower than multi-year norms $(0-24 \%)$ and below the norm $(25-74 \%)$ within the territory of Poland occurred in April (Table 4).

Table 4: Basic meteorological factors and the litter humidity in the particular months of the seasons.

\begin{tabular}{|c|c|c|c|c|c|c|c|c|c|}
\hline $\begin{array}{l}\text { Analysed } \\
\text { factor }\end{array}$ & Year & Hour & IV & $\mathrm{V}$ & VI & VII & VIII & IX & $\begin{array}{c}\text { Fire } \\
\text { season }\end{array}$ \\
\hline \multirow{3}{*}{$\begin{array}{l}\text { Precipitation } \\
{[\mathrm{mm}]}\end{array}$} & $01-05$ & $24 \mathrm{~h}$. & 1.3 & 2.3 & 2.3 & 3.4 & 2.5 & 1.7 & 2.3 \\
\hline & 2006 & $24 \mathrm{~h}$. & 2.0 & 2.6 & 1.8 & 0.8 & 7.0 & 1.6 & 2.6 \\
\hline & 2007 & $24 \mathrm{~h}$. & 0.7 & 3.9 & 3.0 & 5.5 & 3.1 & 3.5 & 3.3 \\
\hline \multirow{6}{*}{$\begin{array}{l}\text { Air } \\
\text { temperature } \\
{\left[{ }^{\circ} \mathrm{C}\right]}\end{array}$} & \multirow{2}{*}{\begin{tabular}{|l|}
$2001-$ \\
2005 \\
\end{tabular}} & 9 & 8.2 & 15.4 & 17.5 & 20.2 & 18.9 & 12.5 & 15.5 \\
\hline & & 13 & 13.5 & 19.9 & 21.5 & 24.7 & 24.5 & 18.9 & 20.5 \\
\hline & \multirow{2}{*}{2006} & 9 & 8.4 & 14.6 & 19.2 & 24.4 & 17.5 & 14.5 & 16.4 \\
\hline & & 13 & 13.7 & 19.4 & 23.9 & 30.6 & 21.5 & 22.0 & 21.9 \\
\hline & \multirow{2}{*}{2007} & 9 & 9.9 & 16.2 & 20.4 & 19.6 & 19.3 & 12.7 & 16.4 \\
\hline & & 13 & 16.1 & 21.0 & 24.3 & 23.2 & 24.2 & 18.3 & 21.2 \\
\hline \multirow{6}{*}{$\begin{array}{l}\text { Relative air } \\
\text { humidity } \\
{[\%]}\end{array}$} & \multirow{2}{*}{$\begin{array}{l}2001- \\
2005 \\
\end{array}$} & 9 & 76 & 74 & 74 & 78 & 80 & 87 & 78 \\
\hline & & 13 & 58 & 58 & 59 & 61 & 58 & 65 & 60 \\
\hline & \multirow{2}{*}{2006} & 9 & 78 & 54 & 69 & 60 & 87 & 87 & 73 \\
\hline & & 13 & 59 & 32 & 53 & 40 & 71 & 62 & 53 \\
\hline & \multirow{2}{*}{2007} & 9 & 65 & 71 & 73 & 78 & 81 & 88 & 76 \\
\hline & & 13 & 45 & 56 & 58 & 65 & 63 & 69 & 60 \\
\hline \multirow{6}{*}{$\begin{array}{l}\text { Litter } \\
\text { humidity } \\
{[\%]}\end{array}$} & \multirow{2}{*}{$\begin{array}{l}2001- \\
2005 \\
\end{array}$} & 9 & 32 & 29 & 31 & 33 & 29 & 31 & 31 \\
\hline & & 13 & 26 & 24 & 24 & 26 & 23 & 30 & 25 \\
\hline & \multirow{2}{*}{2006} & 9 & 36 & 32 & 27 & 15 & 43 & 31 & 31 \\
\hline & & 13 & 29 & 26 & 20 & 11 & 38 & 24 & 25 \\
\hline & \multirow{2}{*}{2007} & 9 & 22 & 30 & 31 & 36 & 32 & 39 & 32 \\
\hline & & 13 & 16 & 25 & 25 & 32 & 26 & 33 & 26 \\
\hline
\end{tabular}

In 2007, the average monthly air temperatures were significantly higher $\left(>2{ }^{\circ} \mathrm{C}\right)$ than multi-year average temperatures nationwide in the second decade of April, in the third decade of May, in the first and second decade of June and in the second decade of July. In the larger part of the country, temperatures above the norm $\left(0.5-2.0^{\circ} \mathrm{C}\right)$ occurred in the first and second decade of August and in the third decade of September.

The lowest monthly average relative humidity of the air $(<70 \%)$ in the forest fire season occurred nationwide in April and, in a large part of the country, in May. In the period May-July, it exceeded, on average, $70 \%$ and in AugustSeptember: $80 \%$. The relative humidity of the air measured at the forest fire 
danger risk forecasting points in the fire season amounted to from $30 \%$ to ca. $85 \%$ and their average values (May-June) were lower than in the multi-year period 2001-2005. Mean values of litter humidity on the national level ranged from 10 to $55 \%$, often exceeding $40 \%$.

The lowest value of litter humidity occurred in April (lower by $10 \%$ than the multi-year average). Low values $(<30 \%)$ occurred also in the second decade of May and June. Mean monthly values in July - September were higher than the multi-year averages by $3-8 \%$. The average for the season was slightly higher (by $1 \%$ ) than the multi-year values.

The highest forest fire danger risk (that was also significantly higher that the multi-year period 2001-2005) occurred in April 2007 (NFFDR $=2.3$ ) and in May-June it was close to the multi-year period. The mean degree of forest fire danger risk for Poland (NFFDR $=1.6$ ) was close to the value referred to as "high risk" (corresponding to " 2 " in the forecast scale). In the remaining months, it was lower by $0.2-0.3$ in comparison with the previous year. The percentage share of occurrence of the third degree of forest fire danger risk for the fire season amounted to, on average, $24 \%$ and was slightly lower (by $2 \%$ ) than the multiyear value. In April, it amounted to $54 \%$, i.e. it was twice as high as in the period 2001-2005; in May (35\%) it was close to the multi-year average, but in September, it amounted to only $1-2 \%$ and in August it was lower by $12-19 \%$ than in the multi-year period (Table 5).

Table 5: $\quad$ NFFDR and the mean indicator $\mathrm{P}_{(\mathrm{NFFDR}=3)}$ in the particular months of the seasons.

\begin{tabular}{|c|c|c|c|c|c|c|c|c|c|}
\hline $\begin{array}{c}\text { Analysed } \\
\text { factor }\end{array}$ & Year & Hour & IV & $\mathrm{V}$ & VI & VII & VIII & IX & $\begin{array}{c}\text { Fire } \\
\text { season }\end{array}$ \\
\hline \multirow{6}{*}{$\begin{array}{l}\text { NFFDR } \\
\text { (average) }\end{array}$} & \multirow{2}{*}{\begin{tabular}{|l}
$2001-$ \\
2005
\end{tabular}} & 9 & 1.6 & 1.8 & 1.8 & 1.6 & 1.7 & 1.2 & 1.6 \\
\hline & & 13 & 1.7 & 1.8 & 1.6 & 1.5 & 1.7 & 1.3 & 1.6 \\
\hline & \multirow{2}{*}{2006} & 9 & 1.5 & 1.7 & 2.1 & 2.7 & 0.9 & 1.1 & 1.7 \\
\hline & & 13 & 1.4 & 1.6 & 2.0 & 2.7 & 0.8 & 1.5 & 1.7 \\
\hline & \multirow{2}{*}{2007} & 9 & 2.3 & 1.8 & 1.7 & 1.4 & 1.5 & 0.9 & 1.6 \\
\hline & & 13 & 2.3 & 1.7 & 1.6 & 1.2 & 1.4 & 1.0 & 1.5 \\
\hline \multirow{6}{*}{$\begin{array}{c}\mathrm{P}_{(\mathrm{NFFDR}=3)} \\
{[\%]}\end{array}$} & \multirow{2}{*}{$\begin{array}{l}2001- \\
2005\end{array}$} & 9 & 26 & 35 & 30 & 23 & 25 & 9 & 25 \\
\hline & & 13 & 29 & 34 & 27 & 24 & 31 & 16 & 27 \\
\hline & \multirow{2}{*}{2006} & 9 & 15 & 30 & 42 & 79 & 3 & 3 & 29 \\
\hline & & 13 & 14 & 32 & 40 & 81 & 4 & 12 & 31 \\
\hline & \multirow{2}{*}{2007} & 9 & 54 & 37 & 26 & 17 & 13 & 1 & 25 \\
\hline & & 13 & 53 & 34 & 24 & 12 & 12 & 2 & 23 \\
\hline
\end{tabular}

\section{Occurrence of forest fires during the fire season}

In 2007, the second and third decade of April and the beginning of May were characterised by more than 100 fires a day. In the remaining part of May and in July-August, that number did not exceed 50 fires a day and in September, there were less than 20 fires a day. The month with the highest number of fires was 
April (39\% of fires, i.e. 2,767); that month, the number of fires was higher then in the period $2001-2005$ by $31 \%$. The next months in terms of number of fires were May (26\%) and June (10\%). The lowest number of fires in the fire season occurred in September (3\%, i.e. 195), that is, almost 6 times less than the average in the multi-year period (see Table 5).

The total number of fires in early Spring (April-May) was visibly higher $(65 \%)$ than the number of fires in the previous year $(26 \%)$ and the multi-year average (38\%) from the period 2001-2005. 90\% of fires occurred in the fire season, i.e. more than in the previous year $(85 \%)$ and in the multi-year period $(81 \%)$.

Table 6: Number of forest fires in he particular months of the seasons.

\begin{tabular}{|c|r|r|r|r|r|r|r|}
\hline Year & April & May & June & July & August & September & $\begin{array}{c}\text { Fire } \\
\text { season }\end{array}$ \\
\hline $2001-2005^{1}$ & 2,250 & 1,818 & 1,318 & 1,041 & 1,232 & 1,144 & 8,803 \\
\hline 2006 & 1,406 & 2,014 & 1,674 & 5,502 & 268 & 488 & 11,340 \\
\hline 2007 & 2,767 & 1,847 & 716 & 369 & 491 & 195 & 6,385 \\
\hline
\end{tabular}

${ }^{1}$ Average from years 2001-2005.

\section{References}

[1] Kwiatkowski, M. \& Ubysz, B., Interdependence of meteorological conditions and large forest fires. In: Large-Area Forest Fires (ed. J. Piwnicki, B. Ubysz), Forest Research Institute, PROFOREST Centre Excellence, Warsaw 2004, p.11-12.

[2] Sakowska, H., A method for assessing fire risk to Polish forests based on predicted change in litter humidity [in Polish]. Dissertation, Forest Research Institute, Warsaw, pp. 128, 2005.

[3] Sakowska H., A survey of fire threat to polish forest during 1991-1997. Coimbra - Portugal $16-20.11 .1998,3^{\text {rd. }}$ International Conference on Forest Fire Research and $14^{\text {th }}$ Conferences on Fire Forest Meteorology, Conference Proceedings, Luso - Coimbra - Portugal $16-20^{\text {th }}$ November1998, pp. 241-252, 1998.

[4] Sakowska, H., Ubysz, B., Walczak, D. \& Kwiatkowski, M., Method for the assessment of large-area forest fire risk in Poland based on predicted change in litter humidity. Proceedings of the 5th International Conference on Forest Fire Research, 27 - 30 November, 2006, Figueira da Foz, Portugal, Edited by D.X. Viegas, ADAI/CEIF University of Coimbra, Portugal, ELSEVIER Amsterdam - Boston - Jena - London - New York Oxford - Paris - Philadelphia - San Diego - St. Louis, Proceedings on the CD-rom, Abstracts in the Forest Ecology and Management Vol. 234, Supplement 1 (2006), 13 pp., index 45, 2006.

[5] Szczygieł, R., Ubysz, B. \& Piwnicki, J., The influence of climate changes on forest fire danger in Poland. Leśne Prace Badawcze, Issue 1, pp. 7-12, 2008 . 
[6] Szczygiel, R., Ubysz, B. \& Zawiła-Niedźwiecki, T., Spatial and temporal trends in distribution of forest fires in Central and Eastern Europe. $22^{\text {nd' }}$ International Meeting for Specialists in Air Pollution Effects on Forest Ecosystems. IUFRO: Forests under Anthropogenic Pressure - Effects of Air Pollution, Climate Change and Urban Development, Forestry 7.01 Symposium: Impacts of air pollution and climate change on forest ecosystems. Riverside, California, USA, 10-16 September 2006. W: "Wildland Fires and Air Pollution", A. Bytnerowicz, M. Arbaugh, C. Andersen and A. Riebau (editors), Elsevier Book Series "Developments in Environmental Science", Series Editor: Dr. S. V. Krupa, Elsevier 2007.

[7] Szczygieł, R., Ubysz, B. \& Piwnicki, J., Impact global warming on the occurrence of forest fire in Poland. Proceedings of the $4^{\text {th }}$ International Wildland Fire Conference, Seville - Spain 13-17 May 2007, Session No. 1 "Global change civil society and wildland fire risk" p. 66, 2007.

[8] Ubysz, B. \& Szczygiel, R., Fire Situation in Poland. International Forest Fire News, No. 27 - July - December, UN ECE/FAO p. 38-64, 2002.

[9] Ubysz, B., The influence factors on the forest fire danger in Poland. XII World Forestry Congress, Québec City, Canada, September 21 to 28, 2003, Forests, Source of Live. Congress Proceedings, B - Forests for the Planet, p. 230, 2003.

[10] Ubysz, B., Szczygieł, R. \& Piwnicki, J., Analysis of the trends in the forest fire risk for recent years in Poland against the background of long-term trends. Proceedings of the 5th International Conference on Forest Fire Research, 27 - 30 November, 2006, Figueira da Foz, Portugal, Edited by D.X. Viegas, ADAI/CEIF University of Coimbra, Portugal, ELSEVIER Amsterdam - Boston - Jena - London - New York - Oxford - Paris Philadelphia - San Diego - St. Louis, Proceedings on the CD-rom, Abstracts in the Forest Ecology and Management Vol. 234, Supplement 1 (2006), 11 pp., index 245, S248, 2006. 